\title{
Transatlantica
}

Revue d'études américaines. American Studies Journal

\section{Reading the Bibliographies of the Women's Rest Tour Association: Cultural Travel in the Long Nineteenth Century}

Julia Carlson

\section{CpenEdition}

\section{Journals}

Electronic version

URL: https://journals.openedition.org/transatlantica/12672

DOI: $10.4000 /$ transatlantica. 12672

ISSN: 1765-2766

Publisher

Association française d'Etudes Américaines (AFEA)

\section{Electronic reference}

Julia Carlson, "Reading the Bibliographies of the Women's Rest Tour Association: Cultural Travel in the Long Nineteenth Century", Transatlantica [Online], 1 | 2018, Online since 18 September 2019,

connection on 01 February 2023. URL: http://journals.openedition.org/transatlantica/12672 ; DOI: https://doi.org/10.4000/transatlantica.12672

This text was automatically generated on 1 February 2023

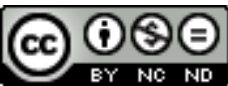

Creative Commons - Attribution-NonCommercial-NoDerivatives 4.0 International - CC BY-NC-ND 4.0 https://creativecommons.org/licenses/by-nc-nd/4.0/ 


\title{
Reading the Bibliographies of the Women's Rest Tour Association: Cultural Travel in the Long Nineteenth Century
}

\author{
Julia Carlson
}

\section{Overview of the WRTA}

1 The increasing involvement of American women in independent transatlantic travel in the late nineteenth century was reflected in the establishment of the Women's Rest Tour Association in Boston in 1891. Founded by poet and biographer Imogen Guiney and fiction writer and editor Alice Brown along with their friends, Anna Murdock and Maria Reed, the WRTA was established accidentally when Brown and Guiney wished to publish A Summer in England: A Handbook for the Use of American Women after having been encouraged by Dr. Clarence Blake of Harvard Medical School to produce a manual for women on the subject of transatlantic travel based on their experience in the British Isles (Norton 3). ${ }^{1}$ When they were unable to obtain copyright for the handbook without being incorporated as an association, the WRTA was formed and soon became a significant women's organization in the New England region where it operated effectively as a private club. The inspiration for the Association's name came from Blake, who subscribed to the belief that travel could serve as a "rest" cure for women; however, it was clear from the start that although there was emphasis on travel as leisure and recovery, there was an even greater emphasis on a progressive feminist agenda establishing the benefits of independent travel for empowering women intellectually and encouraging their productivity. As the Association's first circular from 1892 stated: "A trip abroad is the best of all remedies for tired brains and overstrained nerves, for narrowing or monotonous lives, and inevitably endows the busy woman of intellectual and cultivated tastes with renewed inspiration for better work and greater usefulness" (Norton 3). In her groundbreaking discussion of the 
WRTA, Libby Bishof establishes its wide-ranging significance for women and underscores the ways in which it was "a unique travel organization" that challenged Victorian gender conventions and encouraged women to work cooperatively to create "a community of confident women travelers" (Bischof 155). Combining idealism with practicality, the WRTA focused on boosting women's self-confidence through disseminating information: it was described in its handbook as "a bureau, to which women who have travelled may bring the results of their study and observation for the enriching of others, and where the timorous or inexperienced may apply for aid" ([Guiney and Brown] 5). Benefits offered by the WRTA included access to its lending library of guidebooks, an introduction service for women looking for travel companions, access to the Association's much-coveted Lodging List, and security in the form of voluntary consuls in countries where members traveled. The WRTA's handbook provided advice on everything from managing finances and seasickness to traveling on continental trains and choosing undergarments for hot weather. Moreover, the handbook included two lengthy bibliographies of recommended reading, one for the British Isles and one for the Continent.

2 When examined in depth, these two bibliographies reveal a duality at the heart of the WRTA, not commented upon before, in which a progressive feminism, which encouraged Association members to act and think independently, is balanced against a cultural and social conservatism, which cushioned them from questioning cultural and ethnic prejudice. Helen Norton indicates in her history of the WRTA that it reached out, with an almost missionary fervor, to a coterie of educated, puritanical, middle class New England women who valued learning and cultural experience above all else:

Women of cultivated tastes and small means dreamed of the day when they could save enough money for a European trip. At the outset, it was this group and especially low-salaried teachers, that the Association aimed to reach. In the New England states particularly where "high thinking and plain living" prevailed in many a household, those who stood to benefit from such a project were legion. (Norton 1)

3 Norton also reveals, however, that membership was highly selective. Not only did applicants require references from two current members, they also needed to possess certain character traits: "Meeting admission requirements adequately called for the possession of certain personal qualities such as reliability, good judgment, cooperation, and a sense of responsibility." Moreover, social acceptability was a prerequisite:

These attributes must be supplemented, the Membership Committee insisted, by social acceptability as evidenced by refinement, intelligence, good manners, good taste and an instinct for fair dealing. The society felt deeply responsible for sending out under its name only persons whom the listed proprietors would be glad to receive, and who would creditably represent our country abroad. (Norton 6)

Thus, while there is no question that the WRTA was a progressive organization, it also had a socially conservative side, which manifested itself clearly in the class bias of the Membership Committee and, it will be seen, was equally present in the bibliographies of its handbook.

\section{Progressivism in the WRTA}

Guiney and Brown's progressive ambitions for the WRTA could not be more apparent than they are in the handbook's two lightly annotated bibliographies. Combined, they 
contain over four hundred entries, and although they have been largely overlooked, Norton identified them as "unsurpassed for [their] purpose and the day, and of permanent value" (Norton 3). The feminist focus of the Association is immediately evident in the sheer scale of the bibliographies and in the strong emphasis placed on writing by a wide range of contemporary American and European women writers. William W. Stowe has indicated that in the nineteenth-century United States " $[\mathrm{t}] \mathrm{he}$ traveling class was a reading class, and travel was seen as a preeminently literary activity" (Stowe 13). The WRTA bibliographies exemplify this, and like several writers of travel handbooks before them, such as George P. Putnam and Roswell Park, Guiney and Brown frequently address the reader as a "student" or "scholar," indicating their conviction that transatlantic travel was as much an intellectual journey as a geographical one (Stowe 35). In doing this Guiney and Brown also insert themselves into the ongoing feminist debate about women's education and make a clear connection between education and empowerment for women by equating independent cultural travel with rigorous study. Study is recommended at home before departure and on board ship. The dedicated "student" is given information on how to procure British Library and British Museum reading tickets, while a section of the handbook entitled "English Universities" contains the epigraph “'Study is like the heaven's glorious sun"' from Love's Labour's Lost, and offers detailed information on possibilities for study at Oxford, Cambridge and other universities (54). Pleasure is not excluded as an end result of reading, but there is no doubt that the better informed the woman and the more comprehensive her reading, the more she will become empowered and thereby benefit from her experience of independent travel.

5 In the same way that the bibliographies place the educated woman traveler at the center of the WRTA, they are progressive in the way in which they emphasize the importance of academic study for women, indicating thereby that it is not solely the province of the male reader. Annotations compare the various merits of academic works and literary texts, while critical thinking and analysis are encouraged. Those traveling to Greece, for example, are alerted to the intellectual challenge confronting them:

Even the hurried visitor needs here to have studied the myths and legends of the country. She should have read the "Iliad" and "Odyssey" (Bryant's translation), and have made herself familiar with Bulfinch's "Age of Fable." If she has read the great dramatists, Aeschylus, Sophocles, and Euripides, so much the better. ([Guiney and Brown] 80)

6 The art of Italy, particularly that of the Renaissance, which Van Wyck Brooks observed was enjoying a renaissance of its own in Boston at the time, receives special attention (Brooks 446). Guiney and Brown present it as a scholarly project: "One who would know Italy, her literature, art, and history, needs at least two life-times of study" ([Guiney and Brown] 82). Four pages of the Continental bibliography are devoted to works concerning Italy, including many by recognized Renaissance scholars. American Classical archaeologist Lucy M. Mitchell's A History of Ancient Sculpture (1883) is identified as being "[m]ore entertaining" than German art historian Wilhelm Lübke's History of Sculpture (1863); Jacob Burckhardt's The Civilisation of the Renaissance (1860) is included, along with his guidebook The Cicerone: An Art Guide to Painting in Italy for the Use of Travellers and Students (1873), which is described as "invaluable." British authorities also are highly recommended, including John Addington Symonds whose Renaissance in Italy (1875) is described as "very long and very delightful" ([Guiney and Brown] 83-84). 
7 Throughout the British bibliography the cultural authority of academics and those with connections to Oxford and Cambridge, in particular, is privileged. Oxford historian Edward A. Freeman's English Towns and Districts (1883), erroneously entitled "English Tours and Districts" in the bibliography, comes with the annotation that everything by him and Oxford based historian John Richard Green "abundantly repays hard study" ([Guiney and Brown] 63). Scottish academic David Masson is identified specifically as a "professor of literature in Edinburgh University, [who] has a fund of personal reminiscence, and knows how to set it forth" in Edinburgh Sketches and Memories (1892); Oxford bookseller John Henry Parker's An Introduction to the Study of Gothic Architecture (1881), based on lectures given by him at the Oxford Architectural Society, is described as "a text-book well worth conning" ([Guiney and Brown] 65).

8 Although they address the high-thinking woman with their emphasis on academic preparation for travel, the bibliographies are not limited in focus to academic study. Guiney and Brown show an equal awareness that women's personal empowerment depends upon access to practical information. To this end, they compare the merits of various guidebooks, recognizing their usefulness in spite of the fact that tourists were being ridiculed for relying on them. The bibliography for the British Isles advises the traveler to "[b]uy everywhere the local shilling guides." Baddeley and Ward's Thorough Guides to the Lake District and other regions will lead one "to all places heart can wish"; while English publisher John Murray's popular handbooks are compared to Baedeker's: "'Murray' is perhaps less practical, but brims over with accurate information." Ultimately, it is the more practical Baedeker which receives the WRTA's seal of approval as the traveler is advised: "perhaps Baedeker needs no supplementing, except by general reading" ([Guiney and Brown] 62-63). In fact, when addressing the subject of visiting London, Guiney and Brown go so far as to dismiss their scholarly approach completely, effectively setting themselves up to be caricatured: "The unanimous indorsement of all the women at the bottom of the Rest Tour Association is: Buy a 'Baedeker's London,' study it, sleep with it, and swear by it. With that, and a large-print Bacon's map of London and its environs, you are in a fair way to know all that is knowable of the ancestral capital" ([Guiney and Brown] 33-34). This is quite a risqué statement for the handbook, and as such only serves to underscore the central role that acquisition of practical information plays in creating self-sufficiency for women.

\section{International Coverage of Women Writers}

9 The progressive feminist focus of the bibliographies is further evident in the wideranging international coverage given to women historians, biographers and novelists. While works by women were included in other guidebooks of the period, such as Mary Cadwalader Jones's European Travel for Women (1900), there is no comparison in terms of numbers to what Guiney and Brown offer. Works by English writers such as Maria Francesca Rossetti's A Shadow of Dante (1871), Margaret Oliphant's biography of St. Francis of Assisi and her studies The Makers of Venice (1885) and The Makers of Florence (1876) are all included, as is Oliphant's study of Scottish royalty, Royal Edinburgh (1890), while studies of the French court by Lady Catherine Jackson (1824-1891) are recommended as "entertaining" ([Guiney and Brown] 78). Four works by Irish art historian Anna Brownell Jameson (1794-1860) are recommended, along with Emily Lawless's The Story of Ireland (1887); and visitors to Greece are advised to "[r]ead, at least, Mrs. Mitchell's description of the Parthenon and its neighbors" (81). Equally, 
there is emphasis on biographies of prominent women, such as Mrs. Gaskell's Life of Charlotte Brontë (1857), Agnes Strickland's Lives of the Queens of England (1840), and Frances Gerard's Angelica Kaufmann (1892), a study of the Swiss painter who was one of two female founding members of the Royal Academy, while the dress-conscious traveler is catered to in Georgiana Hill's A History of English Dress from the Saxon Period to the Present Day (1893).

In the same way that they highlight historical studies by and of women, the bibliographies indicate an extensive knowledge of, and support for, fiction by women novelists. In drawing attention to the value of fiction, Guiney and Brown enter into the debate current at the time concerning the impact of the reading of fiction on women, and again they take a progressive stance, arguing strongly for its educational value and defending it as an intellectual exercise, rather than self-indulgence, emphasizing that it has what Kate Flint has termed a "manifestly utilitarian end, offering the reader empirical information about historical events or geographical settings" (Flint 49). "There is a liberal education to be had in a study of English novels," the reader is told, "those who have long steeped their souls in this delightful atmosphere have a knowledge not to be despised concerning customs and people" ([Guiney and Brown] 67). Particularly notable is the number of Continental novelists. Amongst others, Clara Mundt (1814-1873), who wrote under the pseudonym Luise Mühlbach, has three novels included in the German section, while Eugenie John (1825-1887), who wrote under the pseudonym E. Marlitt, is recommended for work that contains "interesting pictures of German life" and as an alternative to Goethe whose "great prose romances [are] only to be attempted by the elect" (80). George Sand (1804-1876) is recommended for Consuelo in the Italian section, while the novels of Swedish feminist Fredrika Bremer (1801-1865), which WRTA members would have known from Little Women where Mrs. March reads from them along with Scott and Maria Edgeworth, are judged as "oldfashioned but delightful" ([Guiney and Brown] 86).

11 The wide-ranging coverage of works by British and Continental women writers is matched in the bibliographies by coverage given to works by women from the Boston and New England regions. When the WRTA was established, high profile women in the Boston literary community, such as Sarah Orne Jewett and Julia Ward Howe, who became the Association's first President, were recruited to lend authority to the organization. Both Guiney and Brown were prominent figures in Boston literary circles, and the bibliographies suggest the solidarity existing between women writers with Boston connections. Well-known writers such as Harriet Beecher Stowe and Mabel Agnes Tincker, whose novel Signor Monaldini's Niece (1879) had gained her an international reputation, are included, along with many authors familiar to readers locally. Susan Hale, who wrote a history of Spain and fictional travel books with her brother Edward Everett Hale, appears several times, although her fictionalized travel book A Family Flight through Spain (1883) is incorrectly identified as co-authored with her brother. Translator and novelist Harriet Waters Preston, known for fiction set in New England, is recommended for her translation of Mistral and her study of French poetry, Troubadours and Trouvères (1876). Virginia W. Johnson, whose family had Boston connections and who lived in Florence where she wrote numerous non-fiction books, including The Lily of the Arno (1891) about Florence and Genoa the Superb: The City of Columbus (1892) also appears, as does Francesca Alexander, the daughter of expatriate portrait painter, Francis Alexander, who grew up in Boston and is recommended for 
her sketches of Italy, Christ's Folk in the Apennine (1887), which are remarked upon for their portrait of "peasant life" ([Guiney and Brown] 85).

\section{Travelogues by American Women Writers}

12 A striking feature of the bibliographies, which lends further support to the feminist agenda of the WRTA, is their extensive inclusion of travelogues by British and American women writers, many of which had their origins in columns in periodicals. Mary Suzanne Schriber has written about the proliferation of travel journalism by women in the 1880s and 1890s, exactly the time of the establishment of the WRTA (Schriber 56). Both Guiney and Brown published regularly in Boston-based periodicals, and they suggest the significance of journalism for women readers when they enthusiastically recommend Poole's Index to Periodical Literature as a resource: “Poole's Index to Periodical Literature' contains, alphabetically arranged, the titles of all articles published in the leading periodicals. These form a rich library in themselves" (75). Numerous travelogues by English writers feature in both bibliographies, but the number of travelogues by writers with Boston connections is particularly notable. Works are included by May Alcott Nieriker, the sister of Louisa May Alcott, who gives advice on studying art in Paris in The Art Student in Paris (1887) and Studying Art Abroad and How to Do It Cheaply, which are singled out as "valuable," and Amy Fay, who became a well-known pianist in Boston and wrote of her studies in Germany with Franz Liszt and others in Music Study in Germany (1880) (79). Interestingly, Alice Brown's travelogue, By Oak and Thorn: A Record of English Days (1896), is excluded, perhaps out of modesty, because, as Bishof has established, Guiney and Brown deliberately concealed their shared authorship of the handbook in order to present it as a collaborative effort (Bishof 156-57). Journalists with Boston connections are well represented in book length accounts of travel by Helen Hunt, who wrote for the Atlantic Monthly; Blanche Willis Howard, who wrote for the Boston Evening Transcript; Mary Elizabeth Blake, whose "Rambling Talks" appeared in the Boston Journal; and Kate Field, whom Henry James used as a model for Henrietta Stackpole in The Portrait of a Lady, and who wrote for periodicals in Boston, New York and Washington. All of these accounts, apart from Fay's, were published in Boston, three in James R. Osgood's Saunterer's Series.

These travelogues by women writers, particularly those with New England connections, can be seen as providing a template for the experience of cultural travel as encouraged by the WRTA. May Alcott Nieriker could have been writing for the WRTA, when she identified her ideal reader in Studying Art Abroad:

I am supposing our particular artist to be no gay tourist, doing Europe according to guide-books, with perhaps a few lessons, here and there, taken only for the name of having been the pupil of some distinguished master, but a thoroughly earnest worker, a lady, and poor [...] wishing to make the most of all opportunities, and the little bag of gold last as long as possible (Nieriker 6-7).

There is a feminist focus in the travelogues, each of which gives prominence to the fact that women are traveling independently without male chaperonage. Stowe has identified European travel in the nineteenth century as "a kind of secular ritual, complete with prescribed actions, promised rewards, and a set of quasi-scriptural writings" (Stowe 19). Although Blake, Howard, and Hunt adhere to prescribed routes and punctuate their travels with observations from similar cultural authorities, valuable advice for women traveling independently is embedded in their texts that 
directly echoes advice provided in the WRTA handbook. Like Nieriker, Howard addresses readers in One Year Abroad, challenging them to be assertive and to resist the security of the guidebook:

Too much guide-book makes you know far too well what to do, where to go, how long to stay. It leaves nothing to imagination, to enthusiasm, to the whim of the moment. Dear guide-book people, don't know so much, don't calculate so much, don't measure and weigh and test everything! Don't speak so much to what you see, and then what you see will speak more to you. (Howard 4)

Similarly, the travelogues encourage women to challenge accepted female behavior. Howard uses a comic scene, in which she and her traveling companions struggle to be polite after being handed spoons so they can share a bowl of soup with a group of workmen in a small Austrian village, as a vehicle for exploring her own cultural prejudices and mocking the culturally conservative voices that dictate what constitutes correct behavior for women:

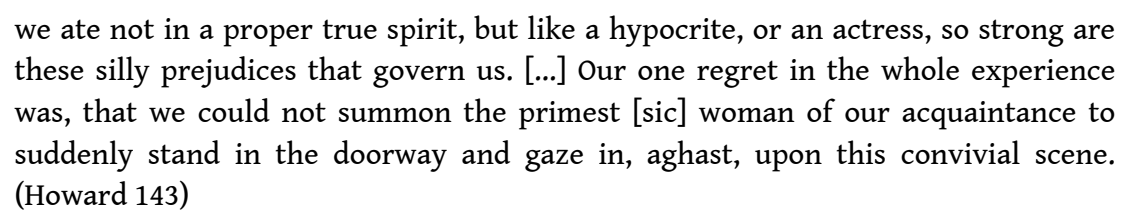
these silly prejudices that govern us. [...] Our one regret in the whole experience was, that we could not summon the primest [sic] woman of our acquaintance to suddenly stand in the doorway and gaze in, aghast, upon this convivial scene. (Howard 143)

Kate Field takes a more assertive approach in Ten Days in Spain as she recounts her journey in the company of a hired courier in September 1873 to interview Emilio Castelar, President of the First Spanish Republic, during a time of civil war when few Americans traveled to Spain. Schriber has argued with regard to Field's collection of travel articles Hap-Hazard (1873) that she uses European travel as an occasion for "travels into the politics of gender as they operate on the homefront" (Schriber 156). This is certainly the case here as Field uses not only her own self-dramatized derringdo to celebrate American womanhood but also her observations of Spanish women as a springboard for discussing political debates in the United States. Describing the physical labor Spanish women engage in, for example, Field challenges the "hot-house rearing" of American women to deride "the miserable sentimental theory that women are born to be sickly dolls" (Field 56). In a similar, more subdued vein Nieriker reinforces the importance the WRTA places on collective action when she recalls how a group of American women art students banded together to defeat sexual discrimination within a Paris atelier, arguing how impressed Parisians were with the "dignity [...] modesty [...] and steadfast purpose" of the women (Nieriker 48-49). Taken together, these travelogues exemplify the way in which Guiney and Brown utilized the bibliographies as agents of empowerment for women, not only using them as tools for educating the reader, but also using them to provide a complex network of role models that supported cultural travel for women by connecting them to their fellow travelers.

\section{Cultural Conservatism in the WRTA}

\section{The Cultural Authority of Boston}

17 At the same time that the bibliographies reveal the progressivism of the WRTA, they expose its deep-seated cultural conservatism. This conservatism is suggested immediately in the high number of texts by authors with connections to the Boston area, indicating the New England region was as central to the bibliographies as it was to 
membership of the organization. In addition to work already mentioned by women writers from the region, works by Ralph Waldo Emerson, Henry Wadsworth Longfellow, William Dean Howells, James Russell Lowell, Henry James, Francis Marion Crawford, who was a nephew of Julia Ward Howe, Thomas Bailey Aldrich, who served as Editor of the Atlantic Monthly, and Nathaniel Hawthorne and his son-in-law George Parsons Lathrop all appear, along with works by historians Edward Everett Hale and William $\mathrm{H}$. Prescott, and Maturin Murray Ballou, the first editor of the Boston Globe, making the bibliographies a showcase for the cultural output of Boston. While the inclusion of women writers from the Boston area certainly can be read from a feminist perspective, once their texts are combined with those of their male counterparts, the provinciality of the WRTA becomes strikingly apparent. In effect, the bibliographies reclaim cultural authority for Boston at a time when, as Brooks indicates, that authority was already passing from New England (Brooks 535). Moreover, they ensure the cultural values of Boston travel abroad with WRTA members who, if they adhere to a carefully curated selection of reading material recommended by Guiney and Brown, need never leave the cultural authority of Boston behind.

\section{Anglophilia}

18 In the same way the bibliographies claim cultural authority for Boston, they also claim it for the British Isles, in general, and England, in particular, further defining the conservatism of the WRTA. British books dominate the bibliographies, and although nationalist perspectives espousing American democracy surface in many of the texts, this nationalism is ultimately overridden by reverence shown for the cultural authority of the British Isles. Brooks identifies a nostalgia for things British as endemic in Boston in the late nineteenth century and explicitly links it not only to an upsurge in travel from Boston to the British Isles, but specifically to Guiney, who moved permanently to England in 1901 (Brooks 462-63). Within the handbook this Anglophilia is on full display and although Guiney and Brown warn the reader against being a "rabid Anglomaniac," their Anglophilia is inescapable ([Guiney and Brown] 51).

Highly romanticized, England is identified as the handbook's "principal theme," the country where the reader "can be most certain to live idyllic days" ([Guiney and Brown] 6-7) and where the artist "may find [...] his earthly paradise" (41). Shakespeare has a dominant position in the form of epigraphs for individual sections throughout the handbook, which opens with a quotation from Richard II: “This royal throne of kings, this scepter'd isle,/ [...] This other Eden, demi-paradise;/ [...] This blessed plot, this earth, this realm, this England"' (4). Epigraphs from Shakespeare precede the bibliographies: “I will read politic authors" from Twelfth Night introduces the bibliography for the British Isles (62), while "Your wisdom be your guide" from Henry IV introduces the Continental one (75). Not surprisingly, British guidebooks, histories and travelogues dominate the bibliography for the British Isles, and the reader is encouraged to view the region through the lens they provide. Novelists are also well represented with Thackeray, Dickens, George Eliot, Jane Austen, William Black, R. D. Blackmore and George MacDonald all included, while Trollope is recommended for "something cathedrally" and "[f]or Parliamentary life," Hardy for Dorsetshire, and Walter Besant's novels for Lyme Regis, Portsmouth, Southwark and the story behind the People's Palace in East London (67-68). Similarly, British poetry is shown to have a practical application, and the reader is advised that "[i]t will not, indeed, be amiss to 
shake hands over again with all the Lake School," and that "Scott is rich in legend, and Wordsworth's 'Excursion' might serve as a wanderer's guide" (65). British writers also are well represented in the Continental bibliography, taking precedence over those from the Continent itself. The poems of Browning are the first works of literature recommended with claims being made for them as "very rich in local references" (75); William Morris's "books on the Wolfings" are recommended as "fine settings of the most precious jewels from northern mythology" in the section on Norway and Sweden (86). In the two-page section on France, only two works by French historians appear, whereas Thomas Carlyle's "The French Revolution" and "Diamond Necklace" are singled out as "wonderful tales dramatically told" (77). Travelogues and novels with French settings similarly are dominated by English writers, with Victor Hugo, Balzac, Erckmann-Chatrian and Daudet the only French writers mentioned, thus further establishing the concept of British cultural authority.

The Anglophilia displayed in the bibliographies is reinforced in the handbook when Guiney and Brown focus upon social codes, demonstrating a cultural insecurity with regard to British social behavior. In keeping with the practical focus of the handbook, the reader is introduced to British etiquette in a section entitled "Social Customs" where she is advised on matters such as the use of calling cards and how to dress for the theatre and garden parties. Although Guiney and Brown reassure the reader "that John Bull and all his family are disposed to like us heartily" and that "[t]o be 'American' [...] is to be endowed with a grace as unique and distinctive as that of French, Italian, or English dames," (51) they also emphasize the important role the traveler has in representing the United States, issuing warnings with regard to social conduct and, like many writers of the period, singling out Daisy Miller as a role model to be avoided:

And above all, remember that, although the eyes of the world may not be upon you, even the kindliest transatlantic relative will not be surprised if there crop out in your behavior the traits of a Daisy Miller or a Red Indian. Therefore, good and gracious country-women, "be vigilant," and resolve to do your nation credit in word, look, and deed. (54)

The duality characterizing the bibliographies surfaces here as Guiney and Brown balance the woman traveler's independence against a more conservative social code, and, significantly, they opt for the latter when they offer the Englishwoman as a role model: "Independent as you may be, do not scorn to imitate one grace of the English woman, be she duchess or chambermaid,-her soft, low voice, that excellence which no American woman has yet attained in its infinitude of sweetness. Listen to it, delight in it, copy it if you can" (54). In this way, Guiney and Brown check the reader, underscoring the culturally conservative side of the WRTA as they signal the superiority of British manners and suggest American assertiveness needs modification in Europe.

21 This duality and the fascination with British social codes are dramatized in Londonbased Canadian Sara Jeannette Duncan's satirical novel, An American Girl in London (1891), recommended for being "full of amusing imaginary experiences" (67). Christopher Mulvey has commented on the obsession American travelers of the nineteenth century had with the British aristocracy and upper classes, and throughout the novel Duncan satirizes this obsession by having her Chicago-born character, Mamie Wick, whose father's wealth comes from manufacturing baking powder, narrate a story of how she attained access to English society in spite of making a succession of faux pas after misreading social codes (Mulvey 147). Mamie identifies herself as a voice for 
democratic principles and independence for women, yet she also reflects a pronounced Anglophile preoccupation with British society. In her social rounds she methodically introduces the reader to the social geography of London and a succession of upper class rituals, including visits to Ascot, a private ball and a country house estate. Throughout, Mamie receives detailed instructions in etiquette from a Lady Torquilin until she is eventually received at Court by the Queen, an event she recalls as the highlight of her trip: "To be perfectly candid, I liked going to Court better than any other thing I did in England" (292). The novel's satirical tone is sustained throughout, with Mamie, who is at one point criticized by a group of proper Bostonians for being like Daisy Miller, being mocked for her gaucherie and the English being exposed for attempting to bolster up their finances with American wealth. Nevertheless, focus is principally upon educating the reader in the intricacies of social behavior within English society, making it, in effect, a conduct book, albeit a tongue-in-cheek one, for an Anglophone readership in the same way that Guiney and Brown use the WRTA handbook, in a more serious fashion, to educate the reader in what constitutes acceptable social behavior while traveling in the British Isles.

\section{Ethnic and Class Prejudice}

The cultural conservatism of the WRTA evident in the privileging of Boston and the British Isles extends further to an ethnic and class bias, which manifests itself at critical points in both the handbook and texts within the bibliographies. Significantly, the Anglophilia of Guiney and Brown plays its part in this ethnic bias when they implicitly exclude those not of British ancestry from their readership by equating a visit to the British Isles with a return to ancestral roots. In "this gracious motherland," readers are told, travelers will find "a kindred people. [...] As someone has cleverly said, England may not actually be 'home' to the younger civilizations which are its offshoots, but 'it contains all the title-deeds"' (6-7). Susan L. Roberson has indicated other writers of the period of British ancestry also referred to England in this way (Roberson 220). Nevertheless, a statement like this could be seen to suggest that Guiney and Brown, consciously or unconsciously, excluded those without British ancestry from their readership and, by extension, from the WRTA.

Three texts focusing on rural Europe and the conditions of peasantry, all of which are highly praised by Guiney and Brown, exemplify the ethnic and class prejudice which seeps out of a significant number of texts in the bibliographies: Margaret Symonds's Days Spent on a Doge's Farm (1893), recommended for its "beautiful and poetic pictures of country life in Italy" (85); Irish writer Jane Barlow's collection of stories, Irish Idylls (1893), identified as offering "[w]onderful and pathetic pictures of peasant life" (68); London-based American expatriates Joseph and Elizabeth Robins Pennell's Play in Provence (1892), singled out for its "incidents of happy travel" (78).

Throughout these texts there is a pronounced avoidance of discussing economic and class inequality and a corresponding emphasis on the poetical and the picturesque, terms used for praise in annotations. In fact, texts that call for social reform would appear to be deliberately omitted from the bibliographies. Zola's naturalistic fiction is excluded from the French section, for example, while only one text is flagged as containing "discussions of social problems": Lee Meriwether's Afloat and Ashore on the Mediterranean (1892), which combines his investigations for the United States 
government into convict labor and the conditions of workingmen with a lighter account of travel (76).

The calculated avoidance of drawing attention to social and economic problems is exemplified in Play in Provence. Elizabeth Robins Pennell defines the narrative angle she and her husband adopt, revealing how they rejected a socioeconomic and historical approach in favor of a poetic one:

Provence has a history as picturesque as itself, but we studied it solely in Roumanille and Mistral and Daudet. [...] Agricultural and industrial problems may darken many a mas, many a vineyard and olive-garden, but never did we go out of our way to find them. [...] Life was gay and beautiful in the sunshine; we never sought the shadows. One need not be forever earnest and solemn, forever on the scent of evil, forever rooting out wrongs. $(38,40,42)$

Focusing chiefly on traditional festivals, such as a bull run in Arles and a display of religious relics at the Maries Feast in Saintes-Maries, the Pennells breezily represent Provence as an antiquarian curiosity. Poverty is romanticized and the Provencal peasant merged metaphorically with the landscape, while ethnic prejudice is used as a tool to distinguish the Provencal from other ethnic groups: "He is gay as his sunshine. I do not mean that he is shiftless and lazy and irresponsibly happy, like the negro or the gipsy. He works hard. He has his bad seasons. Luck at times goes against him, and he has seen days of distress and disaster. But in his toiling and in his poverty he laughs" (Pennell 23-24). Thus, realistic details of working life are airbrushed as the Pennells deploy a strategy of evasion that enables them to create a picturesque lens through which the reader can view Provence and, thereby, avoid seriously questioning the existing social order.

A comparable strategy of evasion exists in Jane Barlow's stories set on tenant farms in the isolated Irish village of Lisconnel. Barlow preserves class distinctions by utilizing a narrative structure in which an educated narrator interprets the behavior of villagers who speak in a dialect that underscores their ethnicity and suggests social inferiority. Although Barlow places considerable emphasis on the material conditions of villagers living in fear of eviction and emigration, she avoids directly addressing controversial political questions, such as the Irish Land Wars, which were actively debated at the time. In the "mournful history" related in the story "Herself," for example, Mrs. O'Driscoll's eviction following the death of her husband and the emigration of her children is viewed fatalistically by her fellow villagers, "as one of those things with which there is no contending" (Barlow 158). Significantly, the narrator never challenges this view, instead emphasizing how Mrs. O'Driscoll is humored and supported by the community. Instead of focusing upon social injustice, then, the story foregrounds "the forlornness of her plight," with the result that Barlow uses pathos to create sympathy for her character but never directly challenges the existing social order (150).

Class and ethnic bias likewise surface in English writer Margaret Symonds's Days Spent on a Doge's Farm where Symonds resists investigating the situation of the peasantry of the Veneto in Vescovana in favor of celebrating the achievements of the widowed English Countess Pisani. Like the Pennells and Barlow, Symonds demonstrates an awareness of the living conditions of the peasantry, and in a chapter entitled "The Melancholy of the Plain," she reflects upon their possible state of mind:

To be truthful, I must state at once that the effect of life in this plain seems to be a saddening one. [...] The very songs which they sang at their work were weighted 
with a human misery which was almost discordant; and lacking any hope or sunshine such as may be reflected back upon a happier soul, they almost startled one. (Symonds 99, 102)

She does not pursue the subject further, however, preferring to romanticize the countryside and focus on the Countess's expert management of Villa Pisani, her transformation of it from a troubled family estate into a successful working farm and her creation of an English style garden on the property. Reflecting the Anglophilia prominent in the bibliographies, the Countess's success is attributed in no small part to her Englishness: "Englishwomen are said to be capable of wonderful things. Certainly I have met one at least in a remote corner of Italy whose life work is no trifling matter" (Symonds 117). Moreover, Symonds has nothing but praise for the Countess's air of command: "I believe if this imperious lady owned Westminster she would attempt to control its slums" (121). In this way, Symonds offers the Countess as a model of paternalistic, aristocratic authority, suggesting it, rather than social change, could hold the solution to social problems. With their positive annotations, these three texts when taken together offer a template for the cultural and social conservatism of the WRTA, underscoring its class and ethnic bias and revealing how it privileged the Anglo-Saxon voice.

\section{Conclusion}

When analyzed closely, the bibliographies of the Women's Rest Tour Association reveal it to have supported cultural travel for women by combining a progressive feminism with a cultural conservatism. In the same way that the WRTA screened applicants, restricting its membership to well-connected, high-minded women who would represent it favorably abroad, so too the bibliographies ensured that reading recommended by the WRTA never veered too far from the cultural authority of the British Isles and Boston. The cultural tour of Europe recommended in the bibliographies is carefully scripted: the healthful, invigorating walks in the countryside advocated in the WRTA's handbook find a parallel in the intellectual challenges offered in the academic program the bibliographies set forth, while the handbook's advice to avoid working class districts of European cities finds a parallel in texts which poeticize the landscape and carefully avoid analysis of contemporary social and economic problems. Unquestionably the WRTA was a progressive organization for its time and it would be incorrect to say that its achievement was radically undermined by its cultural conservatism, nevertheless it was restricted by it and by the cultural biases that both empowered and cushioned its members.

\section{BIBLIOGRAPHY}

BARLOW, Jane. Irish Idylls. New York: Dodd, Mead \& Company, 1893. Internet Archive, Web.

Accessed 1 May 2018. 
BISCHOF, Libby. “A Summer in England: The Women's Rest Tour Association of Boston and the Encouragement of Independent Transatlantic Travel for American Women." Transatlantic Women. Eds. Beth L. Lueck, Brigitte Bailey, and Lucinda L. Damon-Bach. Durham: University of New Hampshire Press, 2012, p. 153-71.

BROOKS, Van Wyck. New England: Indian Summer. New York: E. P. Dutton and Company, 1950.

DUNCAN, Sara J. An American Girl in London. New York: D. Appleton, 1891. Internet Archive, Web. Accessed 1 May 2018.

FIELD, Kate. Ten Days in Spain. Boston: James R. Osgood, 1875, Internet Archive, Web, 1 May 2018.

FLINT, Kate. The Woman Reader, 1837-1914. Oxford: Clarendon Press, 1993.

[GUINEY, Louise Imogen, and Alice BROWN]. A Summer in England With a Continental Supplement: A Handbook for the Use of American Women. Boston: A. J. Ochs, 1900.

HOWARD, Blanche W. One Year Abroad. Boston: James R. Osgood, 1878. Internet Archive, Web. Accessed 1 May 2018.

MULVEY, Christopher. Transatlantic Manners: Social Patterns in Nineteenth-Century Anglo-American Travel Literature. Cambridge: Cambridge University Press, 1990.

NIERIKER, May Alcott. Studying Art Abroad and How to Do It Cheaply. Boston: Roberts Brothers, 1879. Internet Archive, Web. Accessed 1 May 2018.

NORTON, Helen Rich. “The Story of the Women's Rest Tour Association.” MS, Women's Rest Tour Association Collection, Schlesinger Library, Radcliffe Institute for Advanced Study, Harvard University, Cambridge, MA.

PENNELL, Joseph and Elizabeth Robins PENNELL. Play in Provence. New York: The Century Co., 1892. Internet Archive, Web. Accessed 1 May 2018.

ROBERSON, Susan L. "American women and travel writing." The Cambridge Companion to American Travel Writing. Eds. Alfred Bendixen and Judith Hamera. Cambridge: Cambridge University Press, 2009, p. 214-227.

SCHRIBER, Mary Suzanne. Writing Home: American Women Abroad, 1830-1920. Charlottesville: University Press of Virginia, 1997.

STOWE, William W. Going Abroad: European Travel in Nineteenth-Century American Culture. Princeton: Princeton University Press, 1994.

SYMONDS, Margaret. Days Spent on a Doge's Farm. London: T. Fisher Unwin, 1893. Internet Archive, Web. Accessed 1 May 2018.

\section{NOTES}

1. Although Guiney and Brown are not identified as authors on the title page of the handbook, Norton indicates their authorship. 


\section{ABSTRACTS}

The Boston-based Women's Rest Tour Association provided a carefully selected reading list for its "literary pilgrims" from its founding in the 1890s into the twentieth century. As an organization designed to support educated American women traveling on a budget, the WRTA provided members with a range of information to facilitate travel, including a handbook containing two lengthy bibliographies. These bibliographies expose a duality within the organization that balances a progressive feminism with a deep-seated cultural and social conservatism. They exhibit strong support for women writers and educational reading as a tool for personal empowerment at the same time that they show a commitment to the cultural authority of Boston and the British Isles and reveal a notable degree of class bias and ethnic prejudice.

Depuis sa création dans les années 1890 et jusque dans les premières décennies du xx siècle, la Women's Rest Tour Association (WRTA), basée à Boston, eut pour objectif d'apporter son soutien à des Américaines éduquées n'ayant pas les moyens de voyager à grands frais. L'association fournissait à ses membres une panoplie d'informations pour faciliter leur périple, notamment un guide de voyage comprenant deux volumineuses bibliographies révélatrices d'une certaine tension entre un féminisme progressiste et un conservatisme social et culturel. Si elles encouragent le développement de pratiques d'écriture et louent les bienfaits éducatifs de la lecture comme mode d'affirmation et d'émancipation de ces femmes, ces bibliographies n'en restent pas moins inféodées à l'autorité culturelle de Boston et des îles Britanniques, témoignant de préjugés notables ethniques et sociaux.

\section{INDEX}

Mots-clés: Women's Rest Tour Association, clubs de femmes de Boston, voyages culturels, anglophilie, guides de voyage, bibliographie

Keywords: Women's Rest Tour Association, Boston women's clubs, cultural travel, anglophilia, guidebooks, bibliography

\section{AUTHOR}

\section{JULIA CARLSON}

National University of Ireland Galway, julia.kilroy@nuigalway.ie 